\title{
Pneumologia
}

\section{Diagnosis particularities of lung cancer in a young patient without external risk factors - A case report}

\author{
Cristina-Alexandra Brândași,2,*, Raluca Viorica Roșu', Carmen Monica Pop ${ }^{1,2}$
}

1"Iuliu Hatieganu" University of Medicine and Pharmacy Cluj-Napoca, Romania

2"Leon Daniello" Clinical Hospital of Pneumology Cluj-Napoca, Romania

Abstract

English:

Lung cancer is the most common type of cancer worldwide, smoking being the strongest risk factor. We present the case of a non-smoker, a 23-year-old patient, without environmental exposure or personal pathological history, who was hospitalised for dry cough, a unique episode of haemoptysis and low-graded fever. He was admitted with a left basal diminished vesicular murmur, without detectable rales, and normal oxygen saturation. The chest X-ray highlighted left pleural effusion in a medium amount. A chest ultrasound revealed also an adjacent pulmonary consolidation. The cytological examination of the pleural fluid detected the presence of lymphocytes $36 \%$, eosinophils $25 \%$, polymorphonuclear $39 \%$ and frequent red blood cells. Angio-computer tomography confirmed the existence of a left hilar tumour formation with a mass effect on the hilar structures, possibly a few tumoral emboli in the lateral and posterior basal segmentary arteries, a lower left lobe consolidation, a left pleural effusion with hydroaeric level, and a left pneumothorax. The patient required a fibre bronchoscopy that showed us a proliferative infiltrative process, stenosis of the left lower bronchia, and extrinsic compression of the left lower lobe and the 6th segment. Infiltration of mucosa at the left basal pyramid was also detected. The histological examination argued for pulmonary adenocarcinoma. The particularities of the case consist of the lack of exposure to known risk factors for bronchopulmonary neoplasm and the early appearance of lung cancer and its complications in a young patient.

Keywords

\section{Particularități de diagnostic ale cancerului pulmonar la un pacient tânăr fără factori de risc externi - prezentare de caz}

Rezumat

Romanian:

Cancerul pulmonar este cel mai întâlnit tip de neoplazie, a cărei principal factor de risc este fumatul. Prezentăm cazul unui pacient de 23 de ani, nefumător, fără expunere ambientală și fără antecedente personale patologice, cu tuse seacă, hemoptizie episod unic și subfebrilitate. La admitere, murmurul vezicular era diminuat bazal stâng, fără raluri decelabile și saturația de oxigen normală în aerul ambiant. Radiografia pulmonară a evidentiat o colectie pleurală stângă în cantitate medie. Ecografia toracică a pus în evidență și o condensare pulmonară adiacentă. Examenul citologic al lichidului pleural a decelat limfocite 36\%, eozinofile $25 \%$, polimorfonucleare $39 \%$ si frecvente hematii. Angio-computer tomografia a confirmat existenta unei formatiuni tumorale hilare stângi cu efect de masa asupra structurilor hilare, posibili emboli tumorali la nivelul arterelor pulmonare segmentare bazale laterale și posterioare, un focar de condensare la nivelul lobului inferior stâng, o colecție pleurală stângă cu nivel hidroaeric și pneumotorax stâng. Fibrobronhoscopia efectuată a evidențiat un proces proliferativ infiltrativ stenozant al bronhiei lobare inferiore stângi, compresiune extrinsecă la nivelul segmentului 6 , infiltrație de mucoasă și compresie la nivelul piramidei bazale stângi. Examenul histopatologic a pledat pentru un adenocarcinom pulmonar. Particularitatea cazului constă în absența expunerii la factorii de risc cunoscuți pentru apariția neoplasmului bronhopulmonar și apariția precoce a cancerului și a complicațiilor acestuia la un pacient tânăr.

Cuvinte-cheie

adenocarcinom $\bullet$ factori de risc $\bullet$ pacienți tineri

*Corresponding author: Cristina-Alexandra Brândaș

E-mail: cristina.brandas@yahoo.com

ว Open Access. @ 2021 Brândaș et al., published by Sciendo

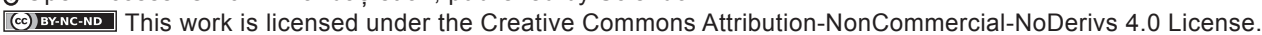




\section{Introduction}

Lung cancer causes the largest number of deaths worldwide annually. A value of $>85 \%$ is represented by non-small-cell lung cancer (NSCLC) (1) with a survival rate of $15.9 \%$ for 5 years (2).

Lung adenocarcinoma represents the most common histological type of NSCLC (3). In recent years, it has replaced squamous cell carcinoma as the leading lung cancer in both sexes (3-5). It accounts for about $40 \%$ of all lung types of cancer (6). More often it is found in women, Asians and young people aged under 45-years old (5-7). It can also be found in non-smokers, although the majority of patients with adenocarcinoma are smokers (6). It arrises in the periphery of the lungs $(6,7)$.

We aimed to present a case of a 23-years-old patient with no external risk factors and with precocious development of complicated lung cancer.

\section{Case presentation}

A 23-years-old male, from a rural environment, presented in our clinical service with a history of a dry cough that started 6 weeks ago, low-grade fever $\left(37.3^{\circ} \mathrm{C}\right)$ and a single episode of haemoptysis in small quantity.

He was seen by his general practitioner, who treated him twice with antibiotics, first with amoxicillin/clavulanic acid for 5 days and then with second-generation cephalosporin for another 5 days. Due to the persistence of the symptoms, the doctor recommended a posteroanterior chest X-ray that revealed a left pleural effusion in medium average. The patient never smoked, had no personal medical history, no professional exposure or drug addiction. His mother had type II diabetes.

On respiratory examination, he presents a diminished left basal vesicular murmur and a normal oxygen saturation in room air. His cardiovascular, abdominal and renal examination had no pathological findings.

After admission, due to the epidemiological conditions created by the coronavirus pandemic, the patient was isolated in a restricted area, and two samples of RT-PCR tests were taken for COVID-19. The results turned out to be negative for both the tests, and so the patient was admitted in an open area with higher access to paraclinical investigations.

Laboratory tests showed high inflammatory syndrome, high eosinophils and monocytes, low lymphocytes and elevated D-dimer. Also, the electrocardiography showed a minor right branch block.

In addition to the left pleural effusion, a thoracic ultrasound pointed out an adjacent pulmonary consolidation. It was necessary to perform a thoracentesis for diagnostic and therapeutic purposes with the evacuation of $100 \mathrm{~mL}$ of haemorrhagic pleural fluid. The fluid was sent to the lab for further investigations. The cytological examination of the pleural fluid detected the presence of lymphocytes $36 \%$, eosinophils $25 \%$, polymorphonuclear $39 \%$, and frequent red blood cells. Biochemical examination of the fluid showed pleural exudate with elevated lactate dehydrogenase. Cytoblock examination concluded a nonspecific inflammatory process.

Computed tomography angiography was necessary to get more information. It confirmed the existence of a left hilar tumour process of $33 / 35 / 50 \mathrm{~mm}$ with associated mass effect (Figure 1) and possibly a few tumoral emboli in the lateral and posterior basal segmentary arteries. Also described were mediastinal lymphadenopathy, bilateral subpleural micronodules, a medium lobe micronodule, a small-sized left pneumothorax (Figure 2), left pleural effusion of $48 \mathrm{~mm}$ with insinuation on the oblique slit and lower left lobe consolidation - pulmonary infarcts associated with secondary atelectasis (Figure 3).

The patient was sent for a fibre bronchoscopy to get bioptic tissue for anatomopathological examination. The fibre bronchoscopy highlighted a proliferative infiltrative process, stenosis of the left lower bronchia, and extrinsic compression of the left lower lobe and the 6th segment. Infiltration of mucosa at the left basal pyramid was also detected. A biopsy fragment was obtained with the mention that it was intense bleeding. The pathological examination argued for pulmonary adenocarcinoma. The patient was sent to complete his diagnosis with genetic tests (epidermal growth factor receptor (EGFR) and anaplastic lymphoma kinase - anaplastic lymphoma kinase (ALK) status).

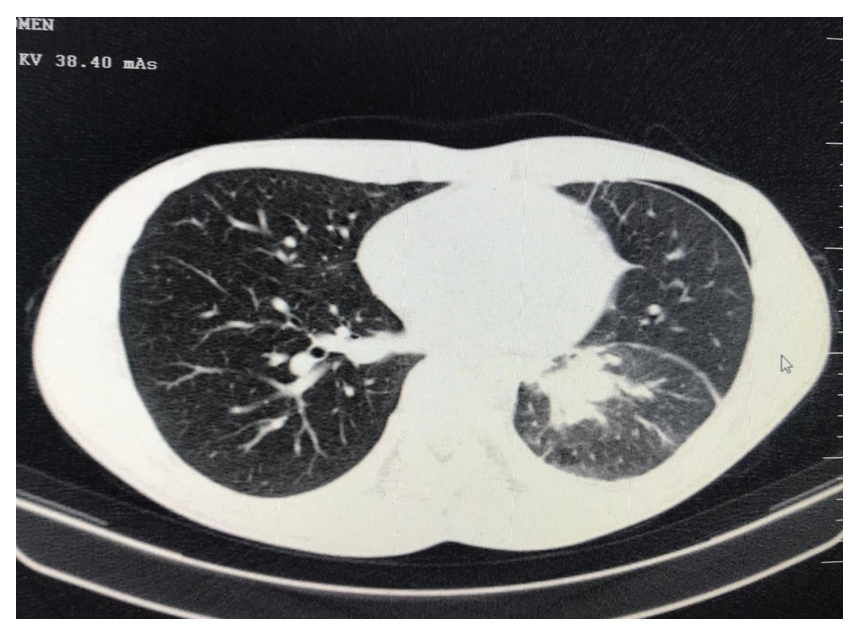

Figure 1. Left hilar tumor process with assoiated mass effect. 


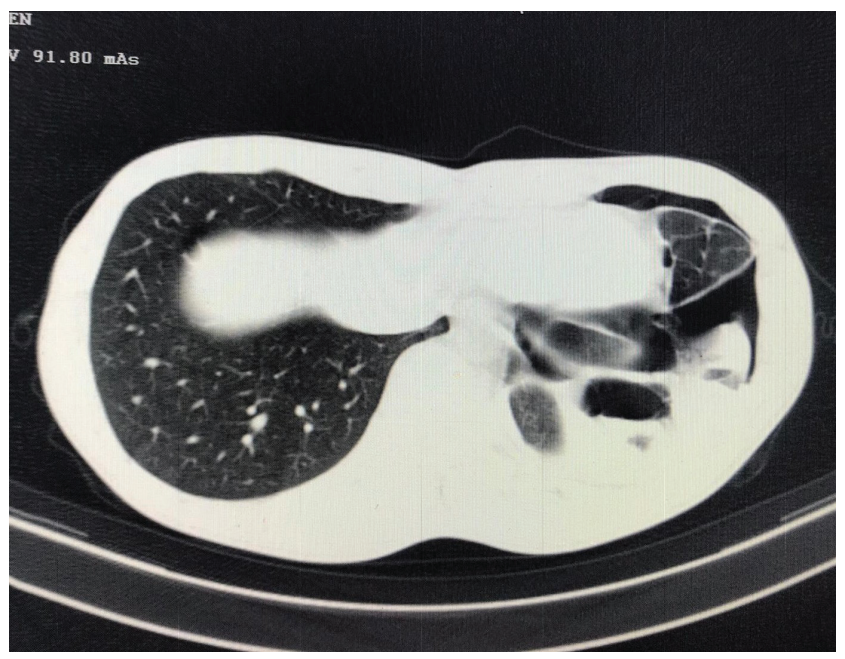

Figure 2. A small left side pneumothorax.

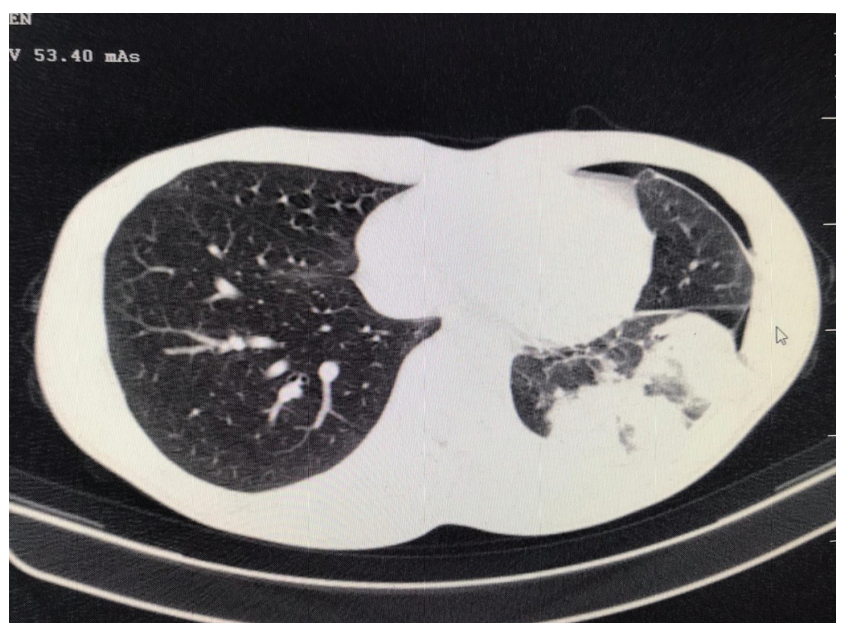

Figure 3. Lower left lobe consolidation.

In this context, the patient was considered unresectable and was directed to the oncology service to initiate the appropriate treatment.

\section{Discussions}

Despite continuous advances in surgical and oncological treatment, lung cancer remains the most common cause of death worldwide $(1,6)$. Non-small cell lung cancer (NSCLC) is the most common type of lung cancer, which occurs frequently in adults, with two predominant subtypes, adenocarcinoma, and squamous cell carcinoma $(7,8)$. Lung adenocarcinoma arises more often in the periphery of the lungs from the mucosal glands (6), and squamous cell carcinoma in the proximal airways and is strongly associated with smoking and chronic inflammation $(1,2)$.

Lung cancer is a rare phenomenon that can be found in young people (9). It is rather considered a disease often found in older people with a history of tobacco use. Other risk factors may include occupational exposure to different kinds of agents (silica, radon and heavy metals), genetic mutations, family history of lung cancer and chronic respiratory diseases (8). Apart from these situations, patients with lung cancer without associated risk factors are also described (6).

Signs and symptoms in lung cancer vary depending on tumour localisation or the extensions of the metastases (8). Early stages may be asymptomatic and are seldom found accidentally on radiographic imaging. Advanced stages may present non-specific symptoms, such as cough, haemoptysis, wheezing, shortness of breath and weight loss (8). Also, paraneoplastic syndromes can occur, but these are pretty rare in adenocarcinoma (10). Diagnosis is often suspected when abnormalities are detected by X-ray, but in $25 \%$ of lung cancer cases, the chest X-ray can be normal (11). Computer tomography or positron emission tomography can describe better the lesions $(11,12)$. However, without histological examination, the diagnosis is often confused with pneumonia, as in our presented case (13).

Our patient was initially treated for dragging pneumonia with associated pleural effusion, without any improvement to antibiotic treatments. The conducted investigations and finally the histopathological examination have helped to determine the real diagnosis. Being an advanced case of lung cancer, surgery is not the therapeutic option. In this situation, oncologic treatment with individualised targeted therapy and/or adjuvant chemotherapy is essential (14). Survival in this type of patient is variable. Different studies described a similar (15) or worse prognosis (16) in young patients with lung adenocarcinoma in comparison with their older counterparts.

\section{Conclusion}

We present a case of a non-smoking patient, with no risk factors, which was diagnosed with an extension form of lung adenocarcinoma at a very young age. Genetic assessment of this kind of patient is mandatory to guide further the individualised targeted therapy.

\section{Ethical approval}

Informed consent was obtained from the patient before publishing the article. 


\section{Conflict of interest}

The authors declare that they have no conflicts of interest.

\section{References}

1. Molina JR, Yang P, Cassivi SD, Schild SE, Adjei AA. Non-small cell lung cancer: Epidemiology, risk factors, treatment, and survivorship. Mayo Clinic Proceedings. 2008;83: 584-594.

2. Chen Z, Fillmore CM, Hammerman PS, Kim CF, Wong KK. Nonsmall-cell lung cancers: A heterogeneous of diseases. Nature Reviews Cancer. 2014;14(8): 535-546.

3. Sun S, Schiller JH, Gazdar AF. Lung cancer in never smokersA different disease. Nature Reviews Cancer. 2007;7: 778-790.

4. Cohen JG, Reymond E, Jankowski A, Brambilla E, Arbib F, Lantuejoul S, et al. Lung adenocarcinomas: Correlation of computed tomography and pathological findings. Diagnostic and Interventional Imaging. 2016;97(10): 955-963.

5. de Groot PM, Wu CC, Carter BW, Munden RF. The epidemiology of lung cancer. Translational Lung Cancer Research. 2018;7(3): 220-233.

6. Myers DJ, Wallen JM. Lung adenocarcinoma. StatPearls Publishing. 2020.

7. Smolle E, Pichler M. Non-smoking-associated lung cancer: A distinct entity in terms of tumor biology, patient characteristics, and impact of hereditary cancer predisposition. Cancers. 2019;11(2): 204.
8. Fishman PA, Elias JA, Fishman JA. Fishman's pulmonary disease and disorders. The McGraw-Hill Companies; 2008, 4th edition.

9. Liu B, Quan X, Xu C, Lv J, Li C, Dong L, et al. Lung cancer in young adults aged 35 years or younger: A full-scale analysis and review. Journal of Cancer. 2019;10(15): 3553-3559.

10. Hutchinson BD, Shroff GS, Truong MT, Ko JP. Spectrum of lung adenocarcinoma. Seminars in Ultrasound CT MRI. 2019;40(3): 255-264.

11. Collins LG, Haines C, Perkel R, Enck RE. Lung cancer: Diagnosis and management. American Family Physician. 2007;75(1): 56-63.

12. Pascoe HM, Knipe HC, Pascoe D, Heinze SB. The many faces of lung adenocarcinoma: A pictorial essay. Journal of Medical Imaging and Radiation Oncology. 2018;62(5): 654-661.

13. Del Ciello A, Franchi P, Contegiacomo A, Cicchetti G, Bonomo L, Larici AR. Missed lung cancer: When, where, and why? Diagnostic and Interventional Radiology. 2017;23(2): 118-126.

14. Araujo LH, Horn L, Merritt RE, Shilo K, Xu-Welliver M, Carbone DP. Ch. 69 - Cancer of the lung: Non-small cell lung cancer and small cell lung cancer. In: Niederhuber JE, Armitage JO, Doroshow JH, Kastan MB, Tepper JE, eds. Abeloff's Clinical Oncology. 6th ed. Philadelphia, Pa: Elsevier; 2020.

15. Liu NS, Spitz MR, Kemp BL, Cooksley C, Fossella FV, Lee JS, et al. Adenocarcinoma of the lung in young patients: The M.D. Anderson experience. Cancer. 2000;88: 1837-1841.

16. Antkowiak JG, Regal AM, Takita H. Bronchogenic carcinoma in patients under age 40. The Annals of Thoracic Surgery. 1989;47(3): 391-393. 